as the most notable educational advance of King George V's reign. The extent of that advance can only be measured by comparison with conditions in pre-War days, when teachers were ill-paid and too often ill-qualified for their important tasks, when the pupils came late and left early-the average length of school-life being less than three years-when nothing had been done to co-ordinate examinations or to reduce their number, when sixth form work was ill-developed and the flow of secondary school pupils to the universities was in some areas a mere trickle and in a large number of schools non-existent. For information as to the conditions which exist to-day the report must be consulted.

In regard to the output to the universities, Table 48 shows that 36 per cent of all the entrants in 1934-35 entered direct from State-aided secondary schools, and this figure does not take account of those who entered after an interval. The figures given on page 49 of the report show that 53 per cent of the open scholarships and exhibitions awarded at Oxford and Cambridge were won by pupils from the State-aided schools, and that in 1935 candidates from these schools gained 56 per cent of the first classes in the final honours schools and triposes (Part II) awarded to candidates from all schools in England and Wales. The flow of pupils to the universities has been encouraged by the institution of State scholarships, which will in future be open to candidates from 'public schools' as well. As to the after careers of the State scholars, it would appear that, in the period 1929-34,
50 per cent of these scholars (men 34 per cent, women 70 per cent) took up teaching, 20 per cent entered other professions and 13 per cent engaged in research. These figures, compared with corresponding figures for the previous five years, show a decrease of 8 per cent in those who entered teaching, an increase of 6 per cent in those entering other professions and 5 per cent in those who took up research work.

It may well be asked whether the report has anything to tell us as to what is actually going on in the class-rooms, practical rooms and science laboratories of the schools with which it deals. The answer must be in the negative. The scientific reader who wants, for example, to know what steps are being taken to devise a general syllabus of elementary science and whether biology is now receiving the attention it deserves, will find no answer to his question in the volume under review. Containing as it does much information which those engaged in educational administration will be glad to have at hand and, in its initial chapter, a valuable survey which the general reader may study with profit, it tells us scarcely anything of the actual work of the schools. Statutory requirements no doubt determine the form of the Board's report, and may to some extent limit its contents; but it is permissible to suggest that if the omission to which we have directed attention could in a measure be made good, the Board's annual reports would be of more general interest and incidentally secure a wider publicity.

F. B. Stead.

\title{
Immunity of Plants to Disease
}

$\mathrm{T}$ HE third International Congress on Comparative Pathology met at Athens on April 15-18, 1936, and there were three main sections, namely, human medicine, veterinary medicine, and plant pathology. Reports of the various deliberations are now being published, and the first volume, from the Section of Plant Pathology, deals with plant immunity against disease-producing agents*.

Dr. E. J. Butler reviewed the problem, and after insisting upon the relatively local reactions of plant tissue, through absence of any circulatory system, he recognized five types of immunity, namely, (1) that following a previous infection and affecting the whole plant, (2) resistance to further local infection in the immediate region of a previous attack, (3) immunity by 'vaccination' with a less virulent strain of the pathogen or of substances formed in diseased tissues, (4) intracellular acquired immunity, and (5) symbiosis, which might vary towards immunity with changing conditions.

Dr. J. Dufrenoy considered the role of amino acids and phenolic compounds in susceptibility or resistance of plants. He showed that resistance is due, not so much to the pre-existence of phenolic compounds in healthy plants before attack, as to the ability of the host to produce such substances when under the stimulus of the entering fungus. Several plant diseases exhibit zones of cells rich in anthocyanin or phenolic compounds, around the point of fungal attack. In Vitis hybrids, many concentric zones

*IIIme. Congrès Internat. de Path. Comparée, Athènes. Tome premier, Rapports, 2me Partie, Section de Path. Végétale, "L'Im- follow attack by mildew, each made during a dry period. The intervening green zones indicate moist intervals.

Several interesting comparisons between animal and plant pathology were drawn by Prof. Ernst Gäumann. Animal immunity is more active than plant immunity, since animal parasites are introduced passively into an active host, whilst plant parasites must themselves gain entrance to a relatively passive victim. Prof. Domenico Carbone agreed with many speakers at the Congress, that there is no evidence for the formation of definite antibodies in plants; but described the diffusion of defensive substances from pieces of plant tissue kept in solutions, or gels, in vitro. Dr. J. Magrou maintained that phenomena which might be termed phagocytosis appear in the plant kingdom. Mycelial masses of the symbiotic mycorrhiza of orchids are, for example, often digested by the host.

Prof. Jean Politis directed attention to the part played by certain substances in the struggle of the plant against a parasite. He stressed the fact that the vacuoles containing such substances are derived from the cell nucleus, and are therefore under the same hereditary influences as the nucleus. The degree of hydration of the vacuole determines the susceptibility or resistance of the host, according to Prof. H. S. Reed, who also proceeded to review the influence of nutritive relations upon host-parasite reactions. Prof. A. J. Riker had a short but interesting paper on "Biochemical and Physical-Chemical Studies on the Bacteria which stimulate Atypical and Pathological Multiplication of Plant Cells". 
Much light can be thrown on the problem of immunity by a study of the resistance of plants to non-living poisons and alkalis. Dr. Winifred E. Brenchley considered the effect of excess mineral nutrients, of inorganic and organic poisons, of gases and sprays, and in the section on resistance to alkalis reviewed much recent work on the plants of chalky soil, and on chlorosis. Prof. F. T. Brooks discussed the resistance of trees to ligneous fungi, and Dr. Tewfik Fahmy described the production of cotton plants immune to the fungus Fusarium vasinfectum var. Egypticum, by breeding and selection.

Prof. L. W. Rischkow reviewed the conditions where resistance of the host was shown towards virus diseases, and Dr. R. N. Salaman dealt with the same subject, but from a different point of view. He showed that a plant could be rendered immune from attack by a virulent form of virus ' $\mathrm{X}$ ', if it were previously vaccinated with a non-virulent strain of the same virus. Dr. Kenneth Smith and Mr. J. P. Doncaster had a paper on "The Particle Size of Plant Viruses".

Immunity against bacterial plant pathogens was treated in an encyclopædic manner by Prof. Tr. Sävulescu, who claimed that the use of vaceines or bacteriophage, in plant therapy, is understood in theory, but is not yet of practical utility. A very extensive bibliography appears at the end of Prof. Săvulescu's paper. Two very informative papers on "The Nature of Resistance of Cereals to Rust", by Dr. E. C. Stakman and Miss Helen Hart, and "The Development of Disease-Resistant Plants", by Dr. H. B. Humphrey, end the volume.

The teacher of mycology, and those plant pathologists who were not fortunate enough to attend the Congress, cannot but be grateful for this volume of reports. It is a welcome gathering of knowledge from many, and often conflicting, points of view, which do not appear so conflicting when tempered by the international atmosphere of the conference, and when bound within the confines of one volume. With the exception of one paper in Italian, all the communications are in English, French or German, and with the provision of a French summary to each article, the contents will be available to most students.

\section{Science News a Century Ago}

\section{Prof. Edward Turner (1798-1837)}

ON February 13, 1837, Prof. Edward Turner died at Hampstead at the age of thirty-nine years through inflammation of the lungs. He had been appointed professor of chemistry at University College, London, in 1828, and his death was regarded as a severe loss not only to the College, but also to many scientific societies in the Empire. Born in Jamaica in 1798, he was taken to Edinburgh at an early age and was educated there, graduating M.D. in 1819. After a period of study under Stromeyer at Göttingen, he began to lecture in Edinburgh and published his "Introduction to the Study and Laws of Chemical Combination", which he afterwards worked into his "Elements of Chemistry", 1827, one of the standard text-books of the time.

At University College, Turner had a large class and his lectures were remarkable for their lucidity. Speaking of his work to the Chemical Society in 1900, Sir Edward Thorpe said he was "an excellent manipulator and his analytical and determination work was of a high order. $\mathrm{He}_{\theta}$ is specially to be remembered for his determination of the atomic weights of lead, chlorine, silver, barium, mercury, nitrogen and sulphur; they were the first atomic weights to be measured by a British chemist and are worthy to be ranked with those of Berzelius". In the course of his work, Turner pointed out that the atomic weights hitherto commonly used by British chemists had been adopted without due inquiry and that several of the most important ones were erroneous, and that the hypothesis that all equivalents are multiples of a whole number of the equivalent of hydrogen was inconsistent with the state of chemical knowledge at the time, being at variance with experiment. His work led to the rejection of Prout's theory, and the position he arrived at was precisely that to which Stas arrived half a century later."

Turner was buried in Kensal Green Cemetery. A marble bust of him was placed in University College by his pupils. He was succeeded by Thomas Graham.

\section{Claude-Pierre Molard (I758-I837)}

By the death on February 13, 1837, of ClaudePierre Molard, the French nation lost a distinguished mechanician who had been one of the most active founders of the National Conservatoire des Arts et Métiers in Paris and its director from 1801 until 1816. When he died, he was president of the Section of Mechanics of the Paris Academy of Sciences. Molard was the elder brother of another well-known mechanician, Emmanuel-François Molard (died 1829), and was borm near St. Claude, Jura, on June 6, 1758. Though the son of poor parents he was able to attend schools at St. Claude and Lyons and became a draughtsman, his ability as such attracting the attention of Jacques de Vaucanson (1709-82), who had formed a collection of machines which he left to the nation, and which eventually formed the nucleus of the collections at the Conservatoire.

In 1785, Molard went to Paris to work under Vandermonde, who was in charge of Vaucanson's collections, and he was made a member of the com. mission appointed by a decree of February 11,1794 , to report on the preservation of monuments and works of art. To this commission belonged Lamarck, Berthollet, Vauquelin, Monge, Prony and other men of science, and it was through them the decree of 19 vendémiare an III. (October 10,1794 ) was passed which led to the foundation of the Conservatoire.

\section{Skey on Muscular Fibre}

Aт a meeting of the Royal Society on February 16, 1837, a paper was read by Frederic Skey entitled "On the Elementary Structure of Muscular Fibre of Animal and Organic Life". The author, said the report, concludes from his microscopic examination of the structures of muscular fibres that those subservient to the functions of animal life have, in man, an average diameter of one 400th of an inch, and are surrounded by transverse circular striæ varying in thickness and in the number contained in a given space. Each of these muscular fibres is divisible into bands or fibrillæ, each of which again is subdivisible into about one hundred tubular filaments, arranged parallel to one another, in a longitudinal direction around the axis of the tubular fibre which they compose, and which contains in its centre a soluble 